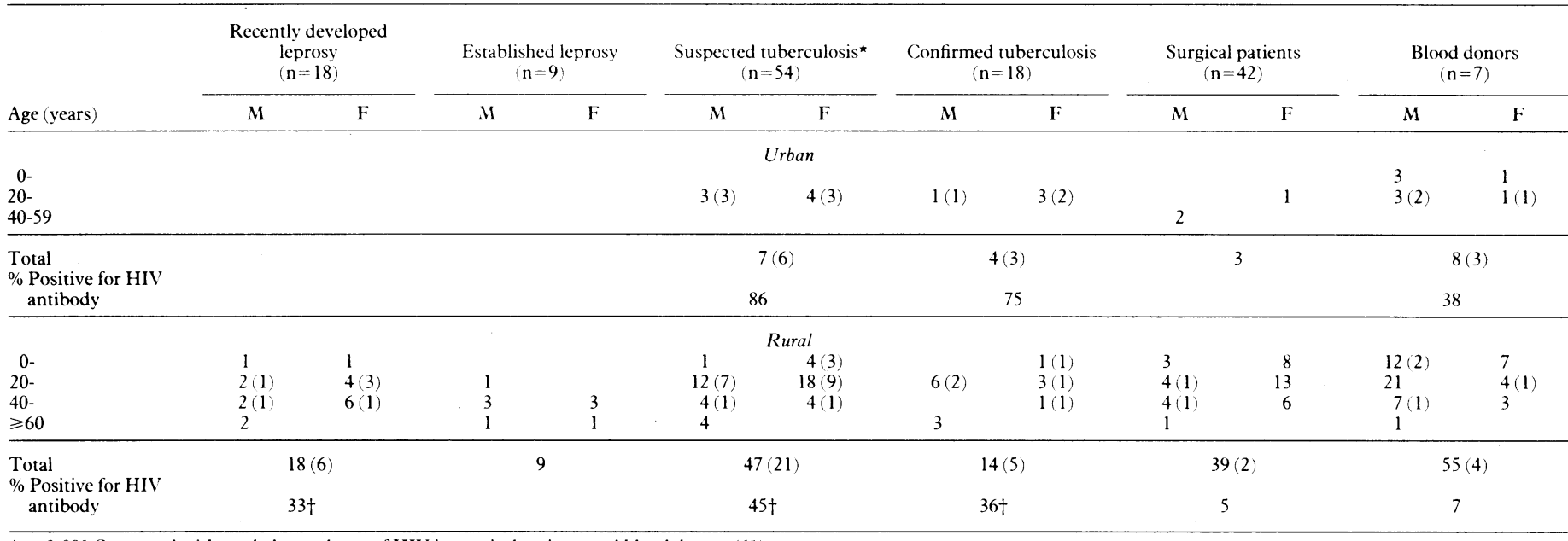

${ }^{\star} \mathrm{p}<0.001$ Compared with pooled prevalence of HIV in surgical patients and blood donors $(6 \%)$.

fIncludes patients positive for acid fast bacilli (confirmed); patients with confirmed tuberculosis are therefore included twice in table.

any change in the epidemiological characteristics of leprosy.

I thank Drs Ian Campbell and Annelies Vreeburg of the Salvation Army Hospital, Dr R J W Rees of LEPRA, and Drs Len Poulter and Jonathan Elford of the Royal Free Hospital School of Medicine. The study was supported by a grant from the British Leprosy Relief Association.
1 Nunn PP, McAdam KPWJ. Mycobacterial infections and AIDS. Br.Med Bull 1988;44:801-3.

2 Pinching AJ. The acquired immune deficiency syndrome with special reference to tuberculosis. Tubercle 1987;68:65-9.

3 Turk JL, Rees RJW. AIDS and leprosy. Lepr Rev 1988;59:193-4.

4 Lamfers EJP, Bastiaans AH, Mravunac M, Rampan FHJ. Leprosy in the acquired immunodeficiency syndrome. Ann Intern Med 1987;107:111-2.

5 Jopling WH. Handbook of leprosy. 3rd ed. London: Heinemann, 1984.

(Accepted 18 November 1988

\section{Unusual complication of use of a Hertel exophthalmometer in a patient with Graves' ophthalmopathy}

\section{R M Pope}

Department of Medicine, King's College School of Medicine and Dentistry, London SE5 8RX R M Pope, MRCP, honorary lecturer

Br Med f 1989;298:365

Proptosis is often measured clinically with a Hertel exophthalmometer, the assessment being an important part of evaluating patients with orbital disease. Correct positioning of the foot plates of the instrument on the lateral orbital rim is essential if reproducible results are to be obtained.' In patients with Graves' ophthalmopathy periorbital swelling is often a prominent feature, and gentle backwards pressure is required to position the instrument accurately. I report an unusual complication of the use of this instrument in a patient with Graves' ophthalmopathy.

\section{Case report}

A 54 year old woman with grade 4 Graves' ophthalmopathy ${ }^{2}$ of four years' duration was reviewed as an outpatient. She had received $550 \mathrm{MBq}$ of iodine-131 two weeks previously for biochemically confirmed hyperthyroidism, which had developed immediately after antithyroid drugs (carbimazole $40 \mathrm{mg}$ and thyroxine $0 \cdot 1 \mathrm{mg}$ daily for 13 months) were stopped. Before the radioiodine treatment her ocular symptoms had included increased lachrymation and diplopia in all directions of gaze, with signs of periorbital oedema, ophthalmoplegia, and proptosis of $22 \mathrm{~mm}$ (right) and $20 \mathrm{~mm}$ (left) with an interocular spacing of $105 \mathrm{~mm}$. Fourteen days after the ${ }^{131}$ I treatment she reported considerable improvement in her periorbital oedema (confirmed by clinical examination) and subjective improvement in diplopia over the previous week.
During a routine examination a doctor with considerable experience of using a Hertel exophthalmometer applied gentle backward pressure to position the instrument. The patient's right upper lid slipped behind her eyeball, completely out of sight, and she experienced considerable discomfort and distress. With some difficulty the lid was repositioned manually. Although profuse lachrymation and injection of the conjunctival vessels occurred, her vision was not impaired and all symptoms and signs resolved without intervention within 48 hours.

\section{Comment}

Exophthalmometry is a safe technique, but this unusual complication shows that care should be taken when positioning the instrument in patients who have both appreciable proptosis and periorbital oedema; particularly when oedema has recently lessened, leaving redundant soft tissue. Traction on such tissue in the patient described clearly caused the upper lid to invert, fortunately without serious consequences. In such patients, I suggest that the limbs of the exophthalmometer should be positioned on the patient laterally to the orbital margin before the correct interocular distance for that patient is set. In this way traction on the lids will be minimised and the complication described will be less likely to occur. Induction of a facial nerve block, although unnecessary on this occasion, may help to reposition a lid that has slipped behind the eye.

R M Pope is funded by the Medical Research Council.

\footnotetext{
1 Wright JE. Proptosis. Ann R Coll Surg 1970;47:323.

2 Werner SC. Modification of the classification of the eve changes of (iraves' disease: recommendations of the ad hoc committee of the American Thyroid Association. F Clin Endocrinol Metab 1977;44:203-4.
} 